\title{
PLANT TISSUE CULTURE IN MUNTINGIA CALABURA IN VITRO CLONAL PROPAGATION, CALLUS INDUCTION AND GERMPLASM CONSERVATION OF 'CERECILLO' MUNTINGIA CALABURA L. (MUNTINGIACEAE)
}

\author{
Duque-Aurazo Yohonatan A. 2, Rojas-Idrogo Consuelo 1, 2, Delgado-Paredes \\ Guillermo E. $1,{ }^{*}$ 《 iD
}

${ }^{1}$ Laboratorio de Cultivo de Tejidos Vegetales y Recursos Genéticos, Facultad de Ciencias

Biológicas, Universidad Nacional Pedro Ruiz Gallo, Juan XXIII 391-Ciudad Universitaria, Lambayeque (Perú)

${ }^{2}$ Laboratorio General de Biotecnología, Vicerrectorado de Investigación (UNPRG), Atahualpa 423, Lambayeque (Perú)

DOI: https://doi.org/10.29121/granthaalayah.v8.i5.2020.197

Article Type: Research Article

Article Citation: Duque-Aurazo Yohonatan A., Rojas-Idrogo Consuelo, and Delgado-Paredes Guillermo E. (2020). PLANT TISSUE CULTURE IN MUNTINGIA CALABURA IN VITRO CLONAL PROPAGATION, CALLUS

INDUCTION AND GERMPLASM CONSERVATION OF 'CERECILLO' MUNTINGIA CALABURA L. (MUNTINGIACEAE). International Journal of Research GRANTHAALAYAH, 8(5), 277-289. https://doi.org/10.29121/granthaa layah.v8.i5.2020.197

Received Date: 16 May 2020

Accepted Date: 31 May 2020

Keywords:

Callus Induction

Micropropagation

Nodal Segments

Rooting

Seasonally Dry Forest

Seed Germination

\section{ABSTRACT}

Muntingia calabura L. (Muntingiaceae) is a fast-growing tree native to tropical America, abundant in the seasonally dry forest of the north coast of Peru. Tissue culture is an effective procedure to produce healthy plants, rapid clonal propagation and several morphogenic process. The objective of this study was to formulate an efficient method for micropropagation, morphogenesis callus induction and germplasm conservation of this species. In this study, seeds, shoot-tips and nodal segments of seedlings were used as explants, inducing various morphogenic processes in different combinations of growth regulators and osmoregulatory substances. In vitro seeds germination was $100 \%$ up to four months after the ripe fruits were collected and after 12 months the germination rate was $0.0 \%$. The highest elongation of shoot was observed with $0.5 \mathrm{mg} \mathrm{L}^{-1} 2 \mathrm{iP}(3.11 \mathrm{~cm})$ although the highest number of shoots formed (18.0 and 16.5) was observed with $0.5 \mathrm{mg} / \mathrm{L} \mathrm{KIN} \mathrm{or} \mathrm{TDZ,}$ respectively, after 30 days of culture. The best callus induction was obtained in 0.5 and $1.0 \mathrm{mg} \mathrm{L}^{-1} \mathrm{TDZ}, 1.0$ and $2.0 \mathrm{mg} \mathrm{L}^{-1} 2,4-\mathrm{D}, 2.0 \mathrm{mg} \mathrm{L}^{-1} \mathrm{NAA}$ or $2.0 \mathrm{mg} \mathrm{L}^{-}$ 1 NAA with 0.1 and $0.5 \mathrm{mg} \mathrm{L}^{-1} \mathrm{BAP}$, after 45 days of culture period. Shoot regeneration (> 10 shoots/explant) was observed with 0.1 to $2.0 \mathrm{mg} \mathrm{L}^{-1} \mathrm{NAA}$. Root induction was observed in all shoots cultured in various concentrations of IBA and NAA-GA3, after 30 days of culture. After two months, well rooted plantlets were transplanted in greenhouse conditions, however, the survival rate was less than $10 \%$. Only in treatment with mannitol $2.0 \%$ in explants without roots, the highest in vitro conservation rate (50\%) was reached, after 6 months of culture, while in the control treatment in culture medium without

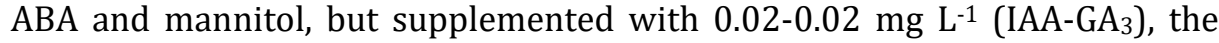
conservation rate reached $100 \%$. The results demonstrated the applicability of tissue culture in the micropropagation and in vitro germplasm conservation of M. calabura. 
Plant Tissue Culture in Muntingia Calabura In Vitro Clonal Propagation, Callus Induction and Germplasm Conservation of 'Cerecillo' Muntingia Calabura L. (Muntingiaceae)

\section{INTRODUCTION}

Muntingia calabura L. (Muntingiaceae), is known in Peru as "cerecillo" and also as "bolina", "ccoillor-panchu", "guinda yumanasa", "iumanasa", "mullaca huayo" (Soukup, 1970). M. calabura is known throughout the world as "Jamaican cherry" and in Malaysia, particularly among the Malay, it is known as "kerukup siam". Other vernacular names have been reported by Mahmood et al. (2014). In the Cronquist classification M. calabura it belongs to the Elaeocarpaceae (Order Malvales) family with about 400 species (Cronquist, 1988); however, in the APG classification the Muntingiaceae family has been included in the order Malvales (APG III, 2009).

Muntingia is a genus of only one species extending from southern Mexico, tropical South America, the Greater Antilles to Brazilian Amazonia and Bolivia; it is also widely cultivated in warm areas in India and Southeast Asia such as Malaysia, Indonesia, and the Philippines (Mahmood et al., 2014). In several Latin American countries, M. calabura is used in traditional medicine. In Peruvian folklore medicine, the flowers and bark are used as antiseptic and to reduce swelling in lower extremities, while the leaves, either boiled or steeped in water, are used to reduce gastric ulcer and swelling of the prostate gland, and to alleviate headache and cold (Zakaria et al., 2007). In Brazil, flowers of M. calabura (pau de seda) have been ordinarily used in Northeastern folk medicine as anti-septic, anti-spasmodic, antidyspeptic, diaphoretic, tranquilizer, tonic and for the treatment of headache, whereas roots are employed as emmenagogue and abortifacient (Correa, 1978; Kaneda et al., 1991). In Mexico, the plant is used to treat measles, mouth pimples, and stomachache (Yasunaka et al., 2005). In Colombia, the infusion of the flowers is used as a tranquilizer and tonic (Kaneda et al., 1991). In different parts of the world where M. calabura has been introduced as Malaysia, Philippinnes, Vietnam, Taiwan and others, various uses in traditional medicine have been reported. A comprehensive review of traditional uses in M. calubra has been published by Mahmood et al. (2014).

Numerous studies on the biological activity of several extracts of different parts of the plant of M. calabura have been published in recent years. A preliminar study, carried out to investigate about the possible antibacterial activity of several leaves extracts of $M$. calabura, found that, at all concentrations tested, the antibacterial activity of aqueous extracts (AEMC) were effective against S. aureus and Kosuria rhizophila while the methanol extracts were effective against Shigella flexneri, Bacilllus cereus, Proteus vulgaris, Aeromonas hydrophila, and K. rhizophila. This activity was not observed with chloroform extracts; however, at the concentration of $4000 \mathrm{ppm}$ and above, aqueous extracts exhibited significant antibacterial activity against Corneybacterium dihptheriae, P. vulgaris, Staphylococcus epidermidis and $A$. hydrophila (Zakaria et al., 2006). In another complementary study it was determined the in vitro antimicrobial activity of various extracts, partitions and fractions of M. calabura leaves against a selected panel of microrganisms such as S. aureus, S. aureus MRSA, Escherichia coli, Pseudomonas aeruginosa, Candida albicans and Microsporum canis, with several MIC and MBC values of various extracts, partitions and fractions (Zakaria et al., 2010). In the evaluation with 32 hexane and ethanol crude extracts of several plants used in Northeastern of Brasil, antibacterial activity was found in flowers hexane extracts of $M$. calabura against Bacillus subtilis, and leaves in ethanol extracts against Staphylococcus aureus and B. subtilis at concentration of $1.0 \mathrm{mg} / \mathrm{mL}$; likewise, leaves in ethanol extracts and stem both hexane and ethanol extracts were not toxic or low toxicity (Ramos et al., 2009).

Various degrees of inhibition were observed with aqueous and methanol extracts of leaf, bark and fruits against bacterial isolates as Micrococcus luteus, Pseudomonas aeruginosa and Bacillus cereus, and fungal phytopathogens as Fusarium sp. and Penicillium sp. (Sibi et al., 2012). Two botanical formulations (Muntingin 4EC and Muntingin 5EC at $2.0 \%$ ) containing stigmasterol, isolated from the methanol extract of $M$. calabura roots, were found to be the optimum concentration for control of early blight (Alternaria solani) of tomato under pot culture conditions, and others fungal pathogens as Fusarium oxysporum f.sp. lycopersici, Pythium sp. and Phytophthora sp. (Rajesh et al., 2014). Extracts of stem, leaves, fruits and flowers from M. calabura were obtained with ethanol, methanol, acetone, acetonitrile and water, and the highest antimicobial potentials were observed for the methanolic extracts against Klebsiella pneumonia, Bacillus subtilis, B. megaterium and Pseudomonas aeruginosa; likewise, this study showed antifouling effect against pathogenic biofilm forming bacteria (Singh et al., 2017).

M. calabura extracts has a potential use against human and plant pathogens, due to the presence of glycosides, flavonoids and tannins as the major biologically active compounds (Sibi et al., 2012). Kaneda et al. (1991) isolated for the very first-time bioactive compounds of M. calabura, reported 12 flavonoids from the methanol extract of roots. Methanol extracts of $M$. calabura leaves was first partitioned into water, petroleum ether, and ethyl acetate, but only the ethyl acetate partition led to identification of 25 compounds consisting of one new and 24 known compounds (Su et al., 2003). In several studies published by Chen et al. (2004, 2005 and 2007), isolation of flavonoids 
was performed on the methanol extract of M. calabura stem bark and isolation of chalcones and flavonoids from the leaves, and prior to the isolation process the methanol extract of leaves was partitioned using several compounds as $\mathrm{H}_{2} \mathrm{O}-\mathrm{CHCl}_{3}, \mathrm{H}_{2} \mathrm{O}$ and n-BuOH. A comprehensive review of phytochemical constituents and properties of M. calabura and several phramacological studies as acute toxicity and cytotoxic, antiproliferative, quinone reductase, antiplatelet aggregation, antibacterial, antioxidant, insecticidal, antinociceptive, anti-inflammatory, antipyretic, antiulcer, antidiabetic, antihypertensive, and cardioprotective activities it was done by Mahmood et al. (2014).

In physiological studies, the antityrosinase activity of the several extracts (aqueous, ethanol, hydroethanol and petroleum ether) from various parts of the plant (leaf, flower and fruit) from M. calabura was determined, and it was found that the hydroethanolic extract of leaves possessed the maximum tyrosinase inhibiting potential among the various parts examined; likewise, the antioxidant activity of leaf extract of the plant was also ascertained by using 2 , 2-diphenyl 1-picryl hydrazil (DPPH) scavenging assay (Balakrishnan et al., 2011). Likewise, chromatographic fingerprinting and free-radical scavenging activity of ethanol extracts of M. calabura leaves and stems at $4.0 \mathrm{mg} / \mathrm{mL}$ exhibited 2,2-diphenyl-1-picrylhydrazyl inhibition of more than $90 \%$ relative to gallic acid, a very high antioxidant activity (Cruiz et al., 2017). Two types of extracts, ethanol and hexane extracts, from M. calabura flowers and fruits, at concentrations ranging from 0.25 to $30.0 \mathrm{mg} / \mathrm{mL}$, were tested them against Plutella xylostella (Lepidoptera) larvae and pupae using leaf disc immersion assay, and all extracts were reported to be toxic to the larvae and pupae stage (Bandeira et al., 2013).

Studies in tissue culture of M. calabura are very scarce. In a pioneering study, somatic embryogenesis and subsequent plantlet regeneration were achieved in callus cultures from immature zygotic embryos using MS semisolid basal medium supplemented with different concentrations of auxins (4.5 $\mu \mathrm{M} 2,4$-D) and cytokinins $(11.6 \mu \mathrm{M}$ $\mathrm{Kn}$ ) (Rout et al., 1996). In a recent paper, in vitro germination and seedlings growth of $M$. calabura in different culture medium: MS 1/2 macronutrients, and Hyponex® Scotts (NPK 6.5-9-19) and Kristalon laranja® Yara (NPK 6-12-36) at $2.0 \mathrm{~g} \mathrm{~L}^{-1}$, respectively, were studied (Pierine et al., 2019). Therefore, the aim of this study was to formulate an efficient method for micropropagation and in vitro rooting, callus induction and germplasm conservation of 'cerecilllo' Muntingia calabura L., an important arborea species of the seasonally dry tropical forest (SDTF) from the north coast of Peru.

\section{MATERIALS AND METHODS}

\subsection{PLANT MATERIAL, FRUITS DESINFESTATION AND CULTURE MEDIUM}

Plants of Muntingia calabura L. were colected from the Cerro Tres Puntas, a SDTF of Pilasca (Salas, Peru). Mature fruits with red or yellow pericarp were surface-sterilized with $70 \%$ ethanol for $60 \mathrm{~s}$ followed by $5 \%$ sodium hypochlorite (solution of commercial bleach Clorox®) for $5 \mathrm{~min}$, rinsed thoroughly with sterile distilled water to remove traces of sodium hypochlorite. The plants have been previously identified by Dr. Guillermo E. DelgadoParedes, botanist at Universidad Nacional Pedro Ruiz Gallo (UNPRG), Lambayeque-Peru, and a voucher specimen (No 18825) has been preserved at the Herbarium Pedro Ruiz Gallo (PRG).

Aseptic seeds per se were inoculated on MS basal medium (Murashige and Skoog, 1962), without plant growth regulators.

\subsection{MICROPROPAGATION, CALLUS INDUCTION, ROOTING AND GERMPLASM CONSERVATION}

The laboratory experiments were conducted at the Plant Tissue Culture and Genetic Resources Laboratory (Facultad de Ciencias Biológicas) and General Biotechnology Laboratory (Vicerrectorado de Investigación), Universidad Nacional Pedro Ruiz Gallo, Lambayeque, Perú.

Shoot-tips or nodal segments of 6-wk-old seedlings were used as a source of explants for in vitro micropropagation, callus induction, rooting and germplasm conservation. All experiments were carried out on MS basal medium with various concentrations and combinations of plant growth regulators. It was used 6benzylaminopurine (BAP), 2iP (N6-(Isopentenyl adenine), Kinetin (KIN) and thidiazuron (TDZ) for micropropagation, 2,4-D (2,4-dichlorophenoxyacetic acid) and NAA (1-naphthaleneacetic acid) for callus induction, IBA (indole-3-butyric acid) and $\mathrm{GA}_{3}$ (Gibberellic acid)-NAA for rooting and ABA (abscisic acid)-mannitol for germplasm conservation. MS medium was supplemented with $100 \mathrm{mg} \mathrm{L}^{-1}$ myo-inositol, $1.0 \mathrm{mg} \mathrm{L}^{-1}$ thiamine- $\mathrm{HCl}$ and 
$2.0 \%$ sucrose $(w / v)$. In all these morphogenic processes each explant (shoot-tips or nodal segment) was implanted in the culture medium formulated for each case. Glass culture tubes $(25 \times 150 \mathrm{~mm})$ containing $15 \mathrm{~mL}$ of medium were used for seeds culture, micropropagation, rooting and germplasm conservation, whereas that $60 \times 50 \mathrm{~mm}$ culture flasks containing $25 \mathrm{~mL}$ medium with aluminum foil caps were used for callus induction.

The pH of the medium was adjusted to 5.8, before autoclaving, with $0.1 \mathrm{~N} \mathrm{HCl}$ or $0.1 \mathrm{~N} \mathrm{NaOH}$ and gelled with $0.7 \%(\mathrm{w} / \mathrm{v})$ bacteriological agar powder (HYMEDIA $®)$ for aseptic explants. All media were autoclaved at $121^{\circ} \mathrm{C}$ and $108 \mathrm{kPa}$ pressure for $20 \mathrm{~min}$. The cultures were established at $25 \pm 2{ }^{\circ} \mathrm{C}$ and maintained in culture room under a $16 \mathrm{~h}$ photoperiod of $45 \mu \mathrm{mol} \mathrm{m}^{-2} \mathrm{~s}^{-1}$ irradiance provided by white fluorescent tubes and with relative humidity of $80 \%$.

\subsection{STATISTICAL ANALYSIS}

Each experiment was repeated three times with 15 explants per replicate. All data were subjected to one-way analysis of variance test (ANOVA) and performed with versión 3.4.0 R software. Tukey's test was used to compare the mean values at the $5 \%$ level.

\section{RESULTS AND DISCUSSION}

\subsection{FRUITS STERILIZATION AND OXIDATIVE BROWNING}

The efficiency of fruits surface sterilization was $100 \%$ and the germination rate was also $100 \%$, for seeds with 0,2 and 4 months of the fruit collection. In seeds grown, 12 months after collection, the germination rate was $0.0 \%$ (Table 1). The asepsis of the seeds is considered per se; however, it is still premature to ensure that M. calabura is an orthodox or recalcitrance (or non-ortodox or desiccation sensitive) species (Obroucheva et al., 2016). A peculiarity in the culture of $M$. calabura seeds was that due to their small size and high mucilage content it was difficult to separate the seeds individually; therefore, the culture was carried out at a rate of 15 to 25 seeds per $150 \times 25 \mathrm{~mm}$ test tube.

Table 1: In vitro seed germination of Muntingia calabura, after 30 days of culture.

\begin{tabular}{|c|c|c|c|}
\hline Months after collection & Number of seeds & Germination (\%) & Contamination (\%) \\
\hline 00 & 100 & 100.0 & 0.0 \\
\hline 02 & 100 & 100.0 & 0.0 \\
\hline 04 & 100 & 100.0 & 0.0 \\
\hline 08 & 100 & 30.0 & 0.0 \\
\hline 12 & 100 & 0.0 & 0.0 \\
\hline
\end{tabular}

MS medium, vitamins and 2.0\% sucrose; without plant growth regulators

Recently, in vitro germination and seedlings growth of $M$. calabura in different culture medium, MS $1 / 2$ macronutrients (control), and Hyponex ${ }^{\circledR}$ Scotts (NPK 6.5-9-19) (HY) and Kristalon laranja® Yara (NPK 6-12-36) (KR) at $2.0 \mathrm{~g} \mathrm{~L}^{-1}$, respectively, were studied, and the culture media MS $1 / 2$ macronutrients proved to be the most efficient for the in vitro development seedlings, with the highest seed germination $(96.54 \%)$ and speed germination (6.43), after 45 days of culture (Pierine et al., 2019). These authors attributed their results to the greater efficiency of the intermediate concentrations of the nitrogenous salts MS and the higher concentrations of $\mathrm{P}$ and $\mathrm{K}$ in relation to the KR medium and lower in relation to the HY medium, which would influence the osmotic relationships and the mobility of the nutrients between the culture medium and the growing seedlings. In the study presented, the germination rate was $100 \%$, even in seeds grown four months after collection.

Seeds explants in MS medium produced slightly browning exudation within a few hours, resulting no toxic and no leading to the death of the tissue as was reported with several species (Deberg and Reed, 1991). 


\subsection{SHOOT ELONGATION AND NODES FORMED OF SEEDLINGS}

After 90 days of culture the seedlings reached a height of $3.02 \mathrm{~cm}$ and an average of 3.8 nodes formed by seedlings, without observing the development of lateral shoots (Table 2); likewise, a profuse roots system was induced. Therefore, this method of obtaining seedlings can be used for the mass propagation of the species, considering that in greenhouse conditions difficulties have been observed in its propagation, where it was found significative interaction between substrate and temperatura (Lopes et al., 2002) and no information on the stem cuttings propagation is found. Own preliminar observations have confirmed the difficulty of obtaining plants from seeds in greenhouse conditions.

Table 2: Shoot elongation and nodes formed of $M$. calabura seedlings obtained in in vitro culture, after 30,60 and 90 days of culture.

\begin{tabular}{|c|c|c|}
\hline Tiempo de evaluación (days) & Shoot elongation (cm) & Nodes formed (No) \\
\hline 30 & $1.3^{\mathrm{c}}$ & $1.0^{\mathrm{c}}$ \\
\hline 60 & $2.2^{\mathrm{b}}$ & $2.4^{\mathrm{b}}$ \\
\hline 90 & $3.0^{\mathrm{a}}$ & $3.8^{\mathrm{a}}$ \\
\hline
\end{tabular}

MS medium, vitamins and $2.0 \%$ sucrose; without plant growth regulators

Values represent the mean of 15 replicates and dissimilar letters indicate significant differences according to Tukey's test $(P \leq 0.05)$.

In the study carried out in M. calabura by Pierine et al. (2019) it was reported that, after 45 days of culture, the shoot elongation was $4.45 \mathrm{~cm}$, resulting slightly exceeding that reporter in our study $(3.02 \mathrm{~cm})$, in 90 days of culture. These differences can be attributed to the MS salts minerals concentrations (half-strenght vs full-strenght) and sucrose $(3.0 \%$ vs $2.0 \%)$ concentrations used. Pierine et al. (2019) did not reported the number of nodes formed by seedlings.

\subsection{SHOOT-TIPS ELONGATION, SHOOT FORMED AND CALLUS INDUCTION IN NODAL SEGMENTS}

The age of the in vitro plantlets used for shoot-tips elongation and nodes formed varied from 2 to 4 weeks and the shoot size from 5 to $10 \mathrm{~mm}$. Obtained results indicated that nodal segments cultured on medium with $2 \mathrm{iP}$ added in the lowest concentration $\left(0.5 \mathrm{mg} \mathrm{L}^{-1}\right)$ had the highest shoot elongation rate $(3.11 \pm 0.5)$ and the difference to the control plants $(0.38 \pm 0.1)$ was statistically significant (Table 3$)$. The lowest shoot elongation rate $(0.13 \pm 0.2)$ was observed for the medium supplemented with the highest used concentration of TDZ (1.0 mg/L) and the difference in comparison to other concentration was significant. However, in this concentration of TDZ the highest nodes formed rate $(16.50 \pm 0.6)$, together with the concentration of KIN $\left(0.5 \mathrm{mg} \mathrm{L}^{-1}\right)(18.00 \pm 2.2)$ were observed, and the difference in comparison to other cytokinins and concentrations was also significant (Table 3). Increasing the cytokinins BAP, KIN, 2iP or TDZ concentrations, from 0.5 to $1.0 \mathrm{mg} \mathrm{L}^{-1}$, led to limiting growth of the shoots, but no the nodes formed with 2iP and TDZ. Only in the medium supplemented with BAP and TDZ callus induction was observed.

Table 3: Shoot elongation, shoot formed and callus induction in nodal segments of M. calabura obtained in in vitro culture, after 30 days of culture.

\begin{tabular}{|c|c|c|c|}
\hline Treatment $\left(\mathrm{mg} \mathrm{L}^{-1}\right)$ & Shoot elongation $(\mathrm{cm})$ & Shoot formed (No) & Callus induction \\
\hline T0: $($ control) & $0.38 \pm 0.1^{\mathrm{c}}$ & $1.50 \pm 0.6^{\mathrm{e}}$ & - \\
\hline T1: $0.5 \mathrm{BAP}$ & $2.09 \pm 0.5^{\mathrm{b}}$ & $10.67 \pm 2.1^{\mathrm{b}}$ & ++ \\
\hline T2: $1.0 \mathrm{BAP}$ & $2.04 \pm 0.5^{\mathrm{b}}$ & $2.67 \pm 1.2^{\mathrm{de}}$ & ++ \\
\hline T3: $0.5 \mathrm{KIN}$ & $2.27 \pm 0.5^{\mathrm{ab}}$ & $18.00 \pm 2.2^{\mathrm{a}}$ & - \\
\hline T4: $1.0 \mathrm{KIN}$ & $1.83 \pm 0.6^{\mathrm{b}}$ & $7.25 \pm 2.9^{\mathrm{bc}}$ & - \\
\hline T5: $0.52 \mathrm{iP}$ & $3.11 \pm 0.5^{\mathrm{a}}$ & $6.50 \pm 0.6^{\mathrm{cd}}$ & - \\
\hline T6: $1.02 \mathrm{iP}$ & $2.76 \pm 0.5^{\mathrm{ab}}$ & $7.50 \pm 1.7^{\mathrm{bc}}$ & - \\
\hline T7: $0.5 \mathrm{TDZ}$ & $0.75 \pm 0.2^{\mathrm{c}}$ & $11.01 \pm 0.8^{\mathrm{b}}$ & +++ \\
\hline T8: $1.0 \mathrm{TDZ}$ & $0.13 \pm 0.2^{\mathrm{c}}$ & $16.50 \pm 0.6^{\mathrm{a}}$ & +++ \\
\hline
\end{tabular}


Plant Tissue Culture in Muntingia Calabura In Vitro Clonal Propagation, Callus Induction and Germplasm Conservation of 'Cerecillo' Muntingia Calabura L. (Muntingiaceae)

Values represent the mean of $15( \pm \mathrm{SD})$ replicates and dissimilar letters indicate significant differences according to Tukey's test $(P \leq 0.05)$.

BAP, 6-benzylaminopurine; KIN, Kinetin; 2iP, N6-(Isopentenyl)adenine; TDZ, thidiazuron

Cytokinins (CKs) are one of the main groups of plant hormones and play an essential role in plant morphogenesis, growth and development. Cytokinins regulate different processes in the life of plant, such as shoot, leaf and root formation, and are associated with cell division in the meristematic zones of a plant as root tip, shoot apical meristem and immature seeds (Kamada-Nobusada and Sakakibara, 2009). Likewise, in plant cell, tissue and organ culture cytokinins are among the most important plant hormones for regulating growth and morphogenesis (van Staden et al., 2008). Among the main CKs used in tissue culture we have BAP, KIN, 2iP, ZEA and TDZ; for example, micropropagation by axillary budding of Quercus ilex was achieved by culturing shoots with zeatin (Martínez et al., 2017), in Phoenix dactylifera acclimatization was improved with KIN (Hassan, 2017), in Heuchera villosa 'Caramel', BA in combination with NAA the regenerated shoots grew normally, without hyperhydricity (Zhao et al., 2017). On the other hand, TDZ is a synthetic cytokinin that induces many responses in tissue culture such as stimuling the induction of callus and shoot regeneration in some plants species as Arachis hypogaea (Akasaka et al., 2000), and in Scutellaria bornmuelleri 0.5 to $4.0 \mathrm{mg} \mathrm{L}^{-1} \mathrm{TDZ}$ induced efficient in vitro organogenesis and regeneration from leaf, stem and petiole explants (Gharari et al., 2019).

\subsection{CALLUS INDUCTION AND SHOOT PROLIFERATION IN STEM WITH NODAL SEGMENTS}

The highest callus induction (++ and +++ , in empirical scale) was observed in medium supplemented with 0.5 to $2.0 \mathrm{mg} \mathrm{L}^{-1}$ 2,4-D, $2.0 \mathrm{mg} \mathrm{L}^{-1} \mathrm{NAA}$ and $2.0 \mathrm{mg} \mathrm{L}^{-1}+0.1$ or $0.5 \mathrm{mg} \mathrm{L}^{-1}$ BAP. Multiple shoots (> 10) were observed in medium supplemented with 0.1 to $2.0 \mathrm{mg} \mathrm{L}^{-1} \mathrm{NAA}$ and the greater elongation of the shoot (4.5) in medium supplemented with $0.1 \mathrm{mg} \mathrm{L}^{-1} \mathrm{NAA}$. In contrats, 2,4-D alone and $2.0 \mathrm{mg} \mathrm{L}^{-1} \mathrm{NAA}+0.5 \mathrm{mg} \mathrm{L}^{-1} \mathrm{BAP}$ did not produce any shoots (Table 4).

Table 4: Callus induction and shoot proliferation in stem with nodal segments of M. calabura, after 45 days of culture.

\begin{tabular}{|c|c|c|c|}
\hline Treatments $\left(\mathrm{mg} \mathrm{L}^{-1}\right)$ & Callus induction & Shoot formed (No) & Shoot elongation $(\mathrm{cm})$ \\
\hline T0: $($ control) & - & 0 & $0^{\mathrm{e}}$ \\
\hline T1: $0.12,4-\mathrm{D}$ & + & 0 & $0^{\mathrm{e}}$ \\
\hline T2: $0.52,4-\mathrm{D}$ & ++ & 0 & $0^{\mathrm{e}}$ \\
\hline T3: $1.02,4-\mathrm{D}$ & +++ & 0 & $0^{\mathrm{e}}$ \\
\hline T4: $2.02,4-\mathrm{D}$ & +++ & 0 & $0^{\mathrm{e}}$ \\
\hline T5: $0.12,4-\mathrm{D}+0.1 \mathrm{BAP}$ & + & 0 & $0^{\mathrm{e}}$ \\
\hline T6: $0.12,4-\mathrm{D}+0.5 \mathrm{BAP}$ & + & $<10$ & $2.24 \pm 0.5^{\mathrm{d}}$ \\
\hline T7: $0.1 \mathrm{NAA}$ & + & $>10$ & $4.50 \pm 0.22^{\mathrm{a}}$ \\
\hline T8: $0.5 \mathrm{NAA}$ & ++ & $>10$ & $1.83 \pm 0.53^{\mathrm{dc}}$ \\
\hline T9: $1.0 \mathrm{NAA}$ & ++ & $>10$ & $2.43 \pm 0.59^{\mathrm{d}}$ \\
\hline T10: $2.0 \mathrm{NAA}$ & +++ & $>10$ & $3.03 \pm 0.34^{\mathrm{c}}$ \\
\hline T11: $2.0 \mathrm{NAA}+0.1 \mathrm{BAP}$ & +++ & 4 & $3.70 \pm 1.1^{\mathrm{b}}$ \\
\hline T12: 2.0 NAA + 0.5 BAP & +++ & 0 & $0^{\mathrm{e}}$ \\
\hline
\end{tabular}

Values represent the mean of $15( \pm \mathrm{SD})$ replicates and dissimilar letters indicate significant differences according to Tukey's test $(P \leq 0.05)$.

2,4-D, 2,4-Dichlorphenoxiacetic acid; BAP, 6-benzylaminopurine; NAA, $\alpha$-naphthaleneacetic acid

-, without callus formation; +, callus $<5 \mathrm{~mm} \emptyset ;++$, callus between 6-10 $\mathrm{mm} \emptyset ;+++$, callus $>10 \mathrm{~mm} \emptyset$.

Auxins are important in many plant species to induce callus and somatic embryogenesis, and 2,4-D and NAA are the plant growth regulators more used for this purpose. However, 2,4-D can produce epigenetic and genetic changes in the cells, such as methylation and mutations in the DNA (Fehér, 2015), and even, 2,4-D has been related to 
abnormal somatic embryos formation (Garcia et al., 2019), and somaclonal variation during indirect organogenesis (Krishna et al., 2016), because in high concentration it disrupts normal genetic and physiological cellular processes.

In Cinnamomum camphora (camphor tree) callus growth was optimized in terms of medium type concentration of plant growth regulators, revealing that MS culture medium containing $2.0 \mathrm{mg} \mathrm{L}^{-1} \mathrm{NAA}$ plus $1.0 \mathrm{mg} \mathrm{L}^{-1} \mathrm{BAP}$ yielded the best combination for callus growth, optimal for the establishment of cell suspensions (Abd et al., 2019). In Isodon amethystoides it was observed that a combination of auxin (IAA or NAA) and cytokinin (BAP) positively influenced callus formation, and the combination of $4.4 \mu \mathrm{M}$ BAP and $2.7 \mu \mathrm{M}$ NAA achieved better callus induction and callus quality (Duan et al., 2019). In all these studies, as in the study conducted with M. calubura, only the auxin supplement and in other cases the auxin-cytokinin combination were necessary.

\subsection{ROOTING OF REGENERATED BUDS}

The highest rooting rate was observed in culture media supplemented with $0.5 \mathrm{mg} \mathrm{L}^{-1}$ IBA (92.8\%) and the combination $0.01 \mathrm{GA}_{3}-0.01 \mathrm{mg} \mathrm{L}-1$ NAA (83.3\%), after 30 days of culture (Table 5). The root system by explant contained more than 30 roots formed with a length between 1.0 to $3.0 \mathrm{~cm}$, optimal condition for its successful transfer to greenhouse conditions. In the rooting process the formation of basal callus was not observed, which is known rooting with basal callus formation is not desirable and adversely affects the survival of plants during the acclimatization.

Table 5: Rooting of regenerated buds of M. calabura, after 30 days of culture.

\begin{tabular}{|c|c|c|c|c|c|}
\hline \multicolumn{2}{|c|}{ Treatments $\left(\mathrm{mg} \mathrm{L}^{-1}\right)$} & \multicolumn{3}{c|}{ Responses (No/\%) } \\
\hline IBA & $\mathrm{GA}_{3}$ & NAA & Rooting & Without rooting & Dead explants \\
\hline 0.0 & 0.0 & 0.0 & $0 / 0.0^{\mathrm{e}}$ & $40 / 100.0^{\mathrm{a}}$ & $0 / 0.0^{\mathrm{c}}$ \\
\hline 0.1 & & & $28 / 68.9^{\mathrm{b}}$ & $9 / 24.4^{\mathrm{c}}$ & $3 / 6.7^{\mathrm{b}}$ \\
\hline 0.5 & & & $37 / 92.8^{\mathrm{a}}$ & $0 / 0.0^{\mathrm{d}}$ & $3 / 7.2^{\mathrm{b}}$ \\
\hline & 0.01 & 0.01 & $33 / 83.3^{\mathrm{a}}$ & $0 / 0.0^{\mathrm{d}}$ & $7 / 16.7^{\mathrm{a}}$ \\
\hline & 0.01 & 0.05 & $18 / 45.0^{\mathrm{c}}$ & $20 / 50.0^{\mathrm{b}}$ & $2 / 5.0^{\mathrm{bc}}$ \\
\hline
\end{tabular}

Values represent the mean of 15 replicates and dissimilar letters indicate significant differences according to Tukey's test $(P \leq 0.05)$.

IBA, indole-3-butyric acid; $\mathrm{GA}_{3}$, gibberellic acid; NAA, $\alpha$-naphthaleneacetic acid

In several studies on in vitro rooting the effect of auxins IBA, IAA and NAA has been fundamental. In Swertia chirayita, an endangered medicinal plant, the higher mean number of roots per microshoots were formed in $5.0 \mu \mathrm{M}$ IBA (Kumar et al., 2019). In Brachystelma glabrum, an Indian endemic species, in vitro shoots were best rooted on half-strenght MS with $0.5 \mathrm{mg} \mathrm{L}^{-1} \mathrm{NAA}$ (Lakshmi et al., 2017). However, in Glossonema varians, a rare Asclepiadaceae of Indian Thar Desert, $0.1 \mathrm{mg} \mathrm{L}^{-1}$ NOA (2-naphthoxyacetic acid) was found to be most suitable for roots induction (Paliwal et al., 2019).

\subsection{IN VITRO GERMPLASM CONSERVATION}

Among the various treatments tested for ABA (0.5 and $\left.1.0 \mathrm{mg} \mathrm{L}^{-1}\right)$, mannitol $(2.0$ and $4.0 \%)$ and the ABAmannitol combination, using nodal segments as explants, with or without adventitious roots, only in treatment with $2.0 \%$ mannitol in explants without roots, the highest in vitro conservation rate (50\%) was reached, after 6 months of culture, while in the control treatment in culture medium without ABA and mannitol, but supplemented with 0.02 $\mathrm{mg} \mathrm{L}^{-1} \mathrm{GA}_{3}-0.02 \mathrm{mg} \mathrm{L}^{-1} \mathrm{IAA}$, the conservation rate reached $100 \%$ (Table 6), although after 9-12 months of conservation it was necessary to subculture them in fresh culture medium. Likewise, plantlets conserved in $2.0 \%$ mannitol showed a poor physiological condition.

In vitro medium-term conservation of tropical plant germplasm, as in our study with SDTF species, is used routinely in many laboratories, with growth reduction by modifying various parameters, such as temperature, culture medium and gaseous environment (Engelmann, 1991). However, methods of conservation of seedless and heterozygous orthodox tropical plant species and those with recalcitrance seeds are still limited (Cha-um and Kirdmanee, 2007). In Roberts' (1973) concept it is unknown if M. calabura is a species with orthodox or recalcitrant 
Plant Tissue Culture in Muntingia Calabura In Vitro Clonal Propagation, Callus Induction and Germplasm Conservation of 'Cerecillo' Muntingia Calabura L. (Muntingiaceae)

seeds. Recalcitrant seeds contain high moisture and are unable to withstand much desiccation, therefore, they remain viable only for a short time (weeks or months) (Engelmann, 1991).

Table 6: In vitro germplasm conservation of $M$. calabura nodal segments, with or without roots, obtained in in vitro culture, after 180 days of culture.

\begin{tabular}{|c|c|c|c|c|c|c|}
\hline \multicolumn{3}{|c|}{ Treatments } & \multicolumn{2}{|c|}{ Explant condition } & \multicolumn{2}{|c|}{ Explant survival (+) and mortality (-) (\%) } \\
\hline No & $\mathrm{ABA}\left(\mathrm{mg} \mathrm{L}^{-1}\right)$ & Mannitol (\%) & With roots & Without roots & + & - \\
\hline \multirow{2}{*}{ T0 } & 0.0 & 0.0 & $*$ & & 100.0 & 0.0 \\
\hline & 0.0 & 0.0 & & $*$ & 100.0 & 0.0 \\
\hline \multirow[t]{2}{*}{$\mathrm{T} 1$} & 0.5 & 0.0 & $*$ & & 0.0 & 100.0 \\
\hline & 0.5 & 0.0 & & * & 0.0 & 100.0 \\
\hline \multirow[t]{2}{*}{$\mathrm{T} 2$} & 1.0 & 0.0 & $*$ & & 0.0 & 100.0 \\
\hline & 1.0 & 0.0 & & $*$ & 0.0 & 100.0 \\
\hline \multirow[t]{2}{*}{ T3 } & 0.0 & 2.0 & $*$ & & 17.0 & 83.0 \\
\hline & 0.0 & 2.0 & & $*$ & 50.0 & 50.0 \\
\hline \multirow[t]{2}{*}{$\mathrm{T} 4$} & 0.0 & 4.0 & * & & 25.0 & 75.0 \\
\hline & 0.0 & 4.0 & & * & 20.0 & 80.0 \\
\hline \multirow[t]{2}{*}{ T5 } & 0.5 & 2.0 & $*$ & & 0.0 & 100.0 \\
\hline & 0.5 & 2.0 & & $*$ & 0.0 & 100.0 \\
\hline \multirow[t]{2}{*}{ T6 } & 0.5 & 4.0 & $*$ & & 0.0 & 100.0 \\
\hline & 0.5 & 4.0 & & $*$ & 0.0 & 100.0 \\
\hline \multirow[t]{2}{*}{$\mathrm{T} 7$} & 1.0 & 2.0 & $*$ & & 0.0 & 100.0 \\
\hline & 1.0 & 2.0 & & $*$ & 0.0 & 100.0 \\
\hline \multirow[t]{2}{*}{ T8 } & 1.0 & 4.0 & $*$ & & 0.0 & 100.0 \\
\hline & 1.0 & 4.0 & & $*$ & 0.0 & 100.0 \\
\hline
\end{tabular}

ABA, abscisic acid

T0 (control): MS, vitamins, $2.0 \%$ sucrose and $0.02 \mathrm{mg} \mathrm{L}^{-1} \mathrm{GA}_{3}$ and 0.02 IAA mg L-1

T1-T8: MS, vitamins, $2.0 \%$ sucrose and $0.02 \mathrm{mg} \mathrm{L}^{-1} \mathrm{GA}_{3}$ and 0.02 IAA mg L-1

Among the various factors studied that limit growth in in vitro conditions are the substances with osmotic properties as mannitol, sucrose and sorbitol. These osmoticum reduce the hydric potential and restrict the water availability to the explants, and reduce mineral uptake by cells through differences in osmotic pressures thereby retarding plant growth (Shibli et al., 2006). In pioneering studies, the addition of mannitol reduces significantly the growth of Colocasia esculenta and Xanthosoma brasiliense shoots (Staritsky et al., 1985). The growth of Solanum tuberosum shoots at $25^{\circ} \mathrm{C}$ is reduced by the addition of $4.0 \%$ mannitol (Espinoza et al., 1985). However, cassava (Manihot esculenta) shoots deteriorate in presence of 0,1\% mannitol and with a storage temperature lower than 20 ${ }^{\circ} \mathrm{C}$ (Roca et al., 1982). In embryogenic cultures of Phoenix dactylifera, addition of $4.0 \%$ or $6.0 \%$ mannitol and $2.0 \%$ sorbitol showed the highest percentage of survival in Bartamoda cultivar (El-Bahr et al., 2016). However, in another Arecaceae species, Elaeis guineensis and E. oleifera, mannitol at 1.0, 2.0, and 3.0\% after 12 months, the temperature of $20^{\circ} \mathrm{C}$ reduced both plant growth and plant survival (Camillo and Scherwinski-Pereira, 2015).

Growth retardants as ABA also can be added for in vitro germplasm conservation. In order to reduce the growth of shooots of $S$. tuberosum, ABA was supplemented in the culture medium (Espinoza et al., 1985); however, those authors indicate that ABA was detrimental to some varieties. In sweet potato (Ipomoea batatas) the best results of survival, growth decrease and green but small leaves were obtained in the treatments that contained 1.0, 1.5 and $2.0 \%$ mannitol; however, growth of the explants was not achieved with 5.0 and $10 \mathrm{mg} \mathrm{L}^{-1} \mathrm{ABA}$, and even the explants died, after 8 months of culture (Rayas et al., 2019). The application of ABA to the culture media was effectively applied to inhibit the growth of cedar shoots (10 mg L-1 ABA) of Cedrela atlantica and C. libani (Renau-Morata et al., 2006). Likewise, a large number of buds from seed explants of Polygonum multiflorum were preserved in MS basal media supplemented with $2.0 \%$ mannitol and $5.0 \mathrm{mg} \mathrm{L}^{-1} \mathrm{ABA}$, and the survival rate was over $70 \%$ with optimal growth and genetic stability (Huang et al., 2006). In in vitro conservation of Piper aduncum and P. hispidinervum 
shoots the supplemented with mannitol $\left(1.0,2.0\right.$ and 3.0\%) or ABA $\left(0,0.5,1.0,2.0\right.$ and $\left.3.0 \mathrm{mg} \mathrm{L}^{-1}\right)$, negatively affected shoot growth, which was evidenced by the low rate of recovery shoots (da Silva and Scherwinski-Pereira, 2011).

These contradictory results seem to be confirmed with the study that shows that even the minimum ABA concentrations were detrimental, while only the lowest concentration of mannitol $(2.0 \%)$ allowed the conservation of $M$. calabura germplasm, although these results cannot be conclusive and further investigation is needed.
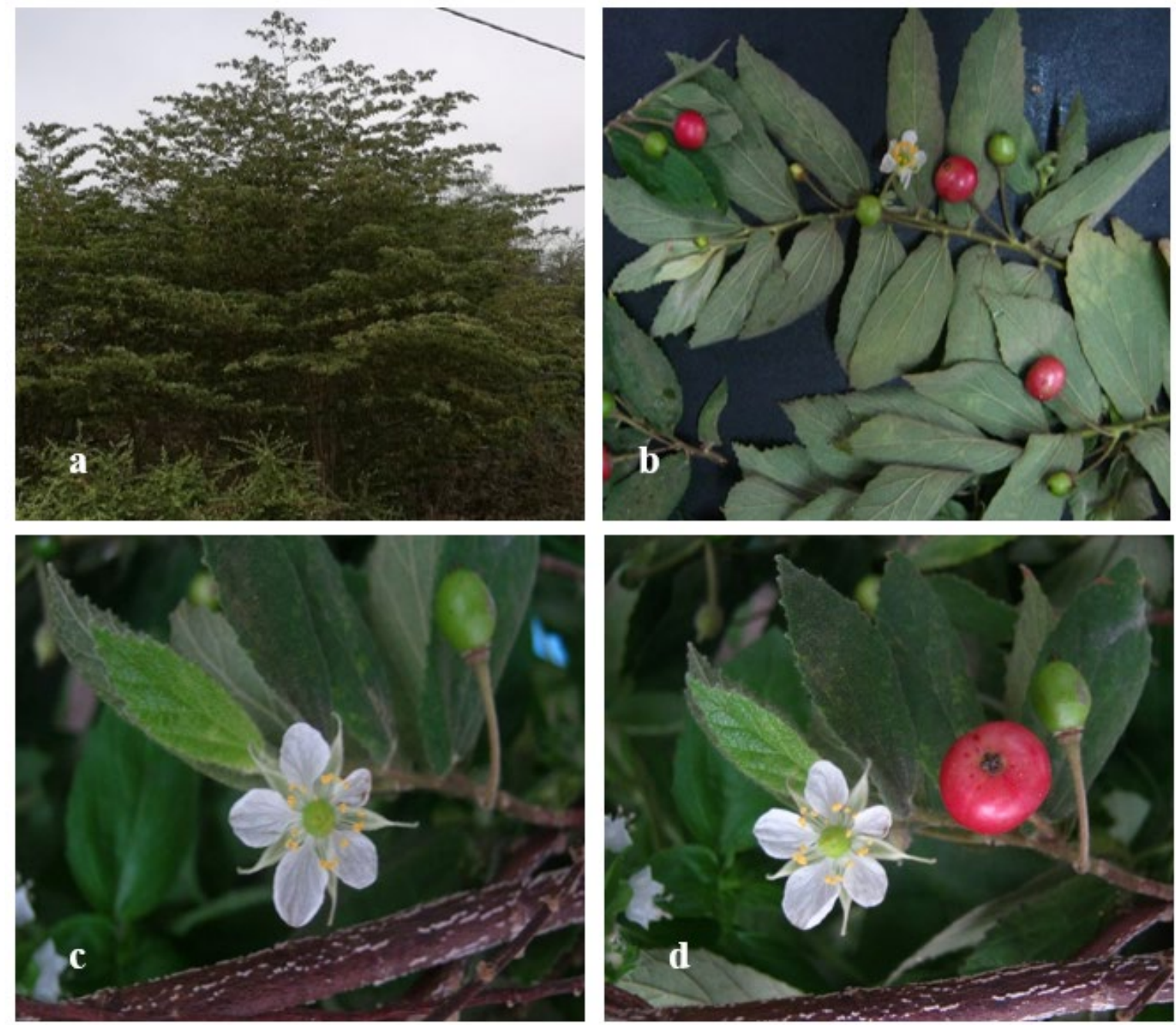

Figure 1: a. Adult plant of Muntingia calabura and b. Branch with leaves, flowers and green and ripe fruits.
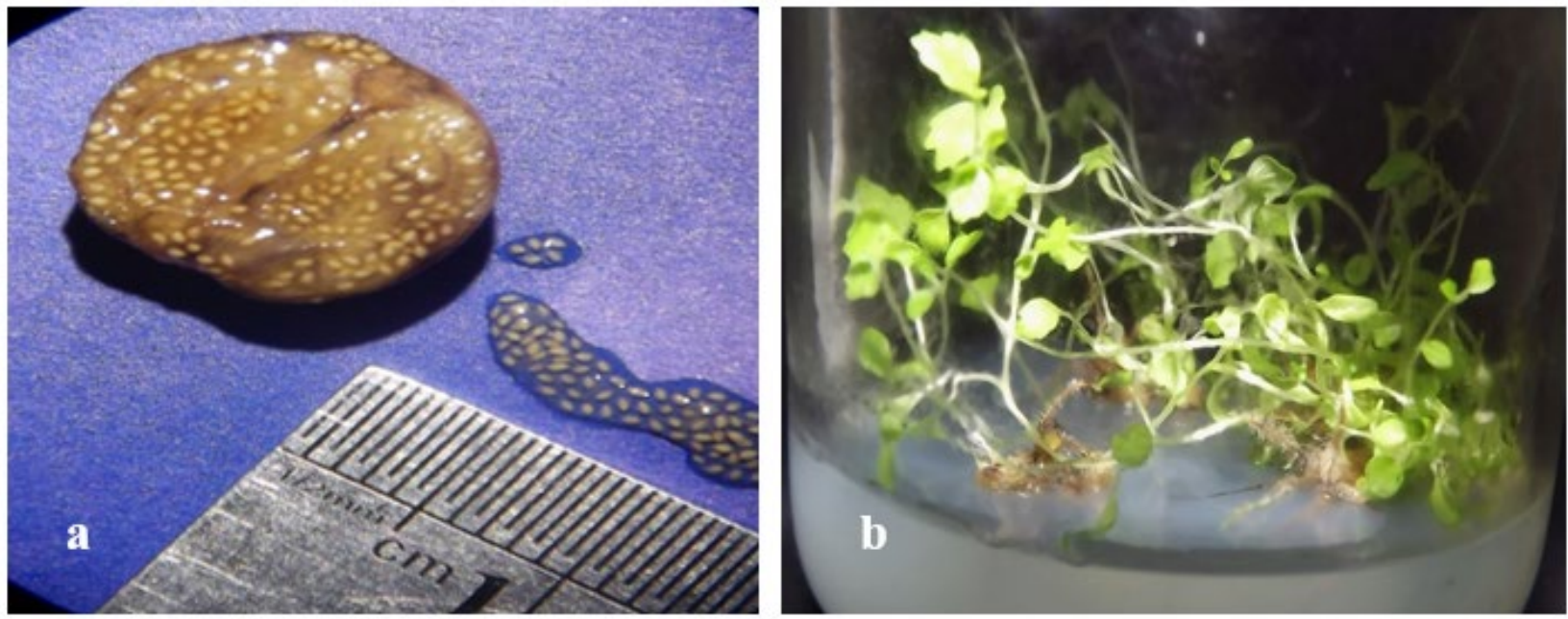

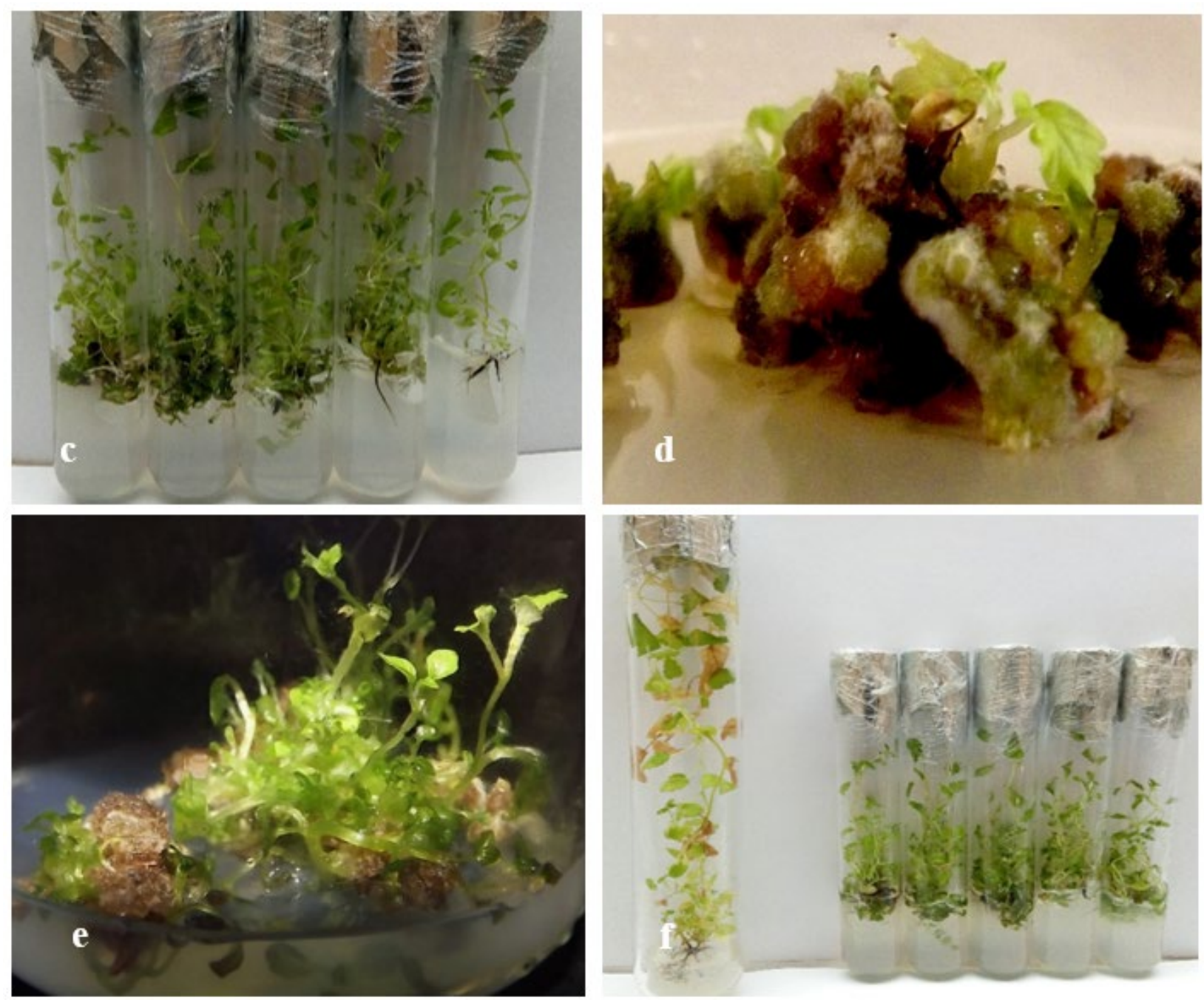

Figure 2: In vitro tissue culture of M. calabura. a. Fruit with numerous seeds, b. Seedlings in germination medium, c. Plant propagated in MS medium with $0.02 \mathrm{mg}$ L-1GA3 - $0.02 \mathrm{mg}$ L-1 IAA d. Callus induction and shoot regeneration in MS medium with $1.0 \mathrm{mg} / \mathrm{L}-1 \mathrm{NAA}$, e. Proliferation of regenerated plants, $\mathrm{f}$. In vitro plants conservation, after nine months (left) and five months (right), in MS medium without manitol and ABA, respectively.

\section{CONCLUSION}

It has been estimated at around 300 species of trees and shrubs that inhabit seasonally dry forest of Peru and Ecuador. Some preliminar studies on the physiology of seed germination of these species indicate that with exception of Fabaceae, the seeds gradually lose their viability. In 'cerecillo' (Muntingia calabura) in vitro germination was $100 \%$ in seeds collected after four months, and $0 \%$ for the ones collected after 12 months. Added to this is the increasing deforestation, natural disasters, increased agriculture and urban planning in natural environments and the dramatic effects of Climate Change. For all these reasons, in vitro plant tissue culture is the most effective tool for the micropropagation of the best genotypes and the conservation of germplasm by limiting growth at minimal rates, in explants (apical shoots) without roots; however, more research is needed.

\section{SOURCES OF FUNDING}

None. 
Duque-Aurazo Yohonatan A., Rojas-Idrogo Consuelo, and Delgado-Paredes Guillermo E

\section{CONFLICT OF INTEREST}

None.

\section{ACKNOWLEDGMENT}

The authors are grateful to Professor Alain Monsalve-Mera and Professor Jorge V.W. Cachay-Wester for English improvements. This research was funded by the General Biotechnology Laboratory-VRINV (UNPRG).

\section{REFERENCES}

[1] Soukup, J. (1970): Vocabulario de los nombres vulgares de la flora peruana. Colegio Salesiano, Lima. 384 p.

[2] Mahmood, N. D., Nasir, N. L. M., Rofiee, M. S., Tohid, S. F. M., Ching, S. M., Teh, L-K., Salleh, M. S. and Zakaria, Z. A, (2014): Muntingia calabura: A review of its traditional uses, chemical properties, and pharmacological observations. Pharmaceutical Biology, 52: 1598-1623.

[3] Cronquist, A. (1988): The evolution and classification of flowering plants. New York Botanical Garden. 555 p.

[4] Angiosperm Phylogeny Group III (APG III). (2009): An update of the Angiosperm Phylogeny Group classification for the orders and families of flowering plants. Botanical Journal of Linnean Society, 16: 105121.

[5] Zakaria, Z. A., Hassan, M. H., Nor Hazalin, N. A. M. and Ghani, A. A. (2007): Effects of various nanopioid receptor antagonist on the antinociceptive activity of Muntingia calabura extracts in mice. Methods and Findings in Experimental and Clinical Pharmacology, 29: 515-520.

[6] Correa, M. P. (1978): Dicionário das Plantas Úteis do Brasil e das Exóticas Cultivadas. Imprensa Nacional, Rio de Janeiro, v.III.

[7] Kaneda, N., Pezzuto, J. N., Soejarto, D. D., Kinghorm, A. D., Famsworth, N. R., Santisuk, T., Tuchinda, P., Udchachon, J. and Reutrakul, V. (1991): Plant anticancer agents: XLVIII. New cytotoxic flavonoids from Muntingia calabura roots. Jounal of Natural Products, 54: 196-206.

[8] Yasunaka, K., Abe, F., Nagayama, A., Okabe, H., Lozada-Pérez, L., López-Villafranco, E., Muñiz, E. E. and ReyesChilpa, R. (2005): Antibacterial activity of crude extracts from Mexican medicinal plants and purified coumarins and xanthones. Journal of Ethnopharmacology, 97: 293-299.

[9] Zakaria, Z. A., Fatimah, C. A., Mat Jais, A. M., Zaiton, H., Henie, E. F. P., Sulaiman, M. R., Somchit, M. N., Thenamutha, M. and Kasthuri, D. (2006): The in vitro antibacterial activity of Muntingia calabura extracts. International Journal of Pharmacology, 2: 439-442.

[10] Zakaria, Z. A., Sufian, A. S., Ramasamy, H., Ahmat, N., Sulaiman, M. R., Arifah, A. K., Zuraini A, and Somchit, M. N. (2010): In vitro antimicrobial activity of Muntingia calabura extracts and fractions. African Journal of Microbiology Research, 4: 304-308.

[11] Ramos, S. C. S., de Oliveira, J. C. S., da Câmara, C. A. G., Castelar, I., Carvalho, A. F. F. U. and Lima-Filho, J. V. (2009): Antibacterial and cytotoxic properties of some plant crude extracts used in Northeastern folk medicine. Brazilian Journal of Pharmacognosy, 19(2A): 376-381.

[12] Sibi, G., Naveen, R., Dhananjaya, K., Ravikumar, K. R. and Mallesha, H. (2012): Potential use of Muntingia calabura L. extracts against human and plant pathogens. Pharmacognosy Journal, 4: 44-47.

[13] Rajesh, R., Jaivel N. and Marimuthu, P. (2014): Muntingia calabura botanical formulation for enhance disease resistance in tomato plants against Alternaria solani. African Jounal of Microbiology Research, 8: 2059-2068.

[14] Singh, R., Prasad, I. S., Deshmukh, N., Gupta, U., Zanje, A., Patil, S. and Joshi, S. (2017): Phytochemical analysis of Muntingia calabura extracts possessing anti-microbial and anti-fouling activities. International Journal of Pharmacognosy and Phytochemical Research, 9: 826-832.

[15] Su, B. N., Park, E. J., Vigo, J. E., Graham, J., Cabieses, F., Fong, H., Pezzuto, J. and Kinghorn, A. (2003): Activityguided isolation of the chemical constituents of Muntingia calabura using a quinine reductase induction assay. Phytochemistry, 63: 335-341.

[16] Chen, J-J., Lin, R-W., Duh, C-Y. and Chen, I-S. (20049: Flavones and cytotoxic constituents from the stem bark of Muntingia calabura. Journal of the Chinese Chemical Society, 51: 665-670. 
Plant Tissue Culture in Muntingia Calabura In Vitro Clonal Propagation, Callus Induction and Germplasm Conservation of 'Cerecillo' Muntingia Calabura L. (Muntingiaceae)

[17] Chen, J. J., Lee, H. H., Duh, C. Y. and Chen, I. S. (2005): Cytotoxic chalcones and flavonoids from the leaves of Muntingia calabura. Planta Medica, 71: 970-973.

[18] Chen, J. J., Lee, H. H., Shih, C. D., Liao, C. H., Chen, I. S. and Chou, T. H. (2007): New dihydrochalcones and antiplatelet aggregation constituents from the leaves of Muntingia calabura. Planta Medica, 73: 572-577.

[19] Balakrishnan, K. P., Narayanaswamy, N. and Duraisamy, A. (2011): Tyrosinase inhibition and anti-oxidant properties of Muntingia calabura extracts: in vitro studies. International Journal of Pharma and Bio Sciences, 2: 294-303.

[20] Cruiz, W. P., Orejudos, R. and Martin-Puzon, J. J. (2017): Chromatographic fingerprinting and free-radical scavenging activity of ethanol extracts of Muntingia calabura L. leaves and stems. Asian Pacific Journal of Tropical Biomedicine, 7: 139-143.

[21] Bandeira, G. N., Gomes da Camara, A., de Moraes, M. M., Barros, R., Muhammad, S. and Akhtar, Y. (2013): Insecticidal activity of $\mathrm{M}$. calabura extracts against larvae and pupae of diamondback, Plutella xylostella (Lepidoptera, Plutellidae). Journal of King Saud University - Science, 25: 83-89.

[22] Rout, G. R., Samantaray, S. and Das, P. (1996): In vitro somatic embryogenesis and plantlet regeneration in callus culture of Muntingia calabura L. Plant Tissue Culture, 6: 15-24.

[23] Pierine, F. R., Gianini, P. F., and Pedroso-de-Moraes, C. (2019): Germinação e crescimento de plântulas in vitro de Muntingia calabura L. (Muntingaceae) submetida a diferentes meios de cultivo. Iheringia, Série Botânica, 74: e2019002.

[24] Murashige, T. and Skoog, F. (1962): A revised medium for rapid growth and bioassays of tobacco cultures. Physiologia Plantarum, 15: 473-497.

[25] Obroucheva, N., Sinkevich, I,. and Lityagina S. (2016): Physiological aspects of seed recalcitrance: a case study on the tree Aesculus hippocastanum. Tree Physiology, 36: 1127-1150.

[26] Deberg, P. C. and Reed, P. E. (1991): Micropropagation. In: Debergh, P. C. and Zimmerman, R. H. (eds.) Micropropagation Technology and Application. Kluwer Academic Publishers, Dordrecht, pp. 1-14.

[27] Lopes, J. C., Pereira, M. D. and Martins-Filho, S. (2002): Germinação de sementes de calabura (Muntingia calabura L.) Revista Brasileira de Sementes, 24: 59-66.

[28] Kamada-Nobusada, T. and Sakakibara, H. (2009): Molecular basis for cytokinins biosynthesis. Phytochemistry 70:444-449.

[29] van Staden, J., Zazimalova, E. and George, E. F. (2008): Plant growth regulators II: cytokinins, their analogues and antagonists. In: George EF, Hall M, De Kerk GJ (eds). Plant Propagation by Tissue Culture. Springer, Dordrecht. Pp. 205-226.

[30] Martínez, M. T., Corredoira, E., Vieitez, A. M., Cernadas, M. J., Montenegro, R., Ballester, A., Vieitez, F. J. and San José, M. C. (2017): Micropropagation of mature Quercus ilex L. trees by axillary budding. Plant Cell, Tissue and Organ Culture, 131: 499-512.

[31] Hassan, M. M. (2017): Improvement of in vitro plantlet acclimatization rate with kinetin and Hoagland solution. In: Al-Khayri, J. M., Jain, S. M. and Johnson, D. V. (eds.). Date Palm Biotechnology Protocols. Vol. I. Tissue Culture Applications. Springer, New York. pp. 185-200.

[32] Zhao, H. Q., He, Q. H., Song, L. L., Hou, M. F. and Zhang, Z. G. (2017): In vitro culture of Heuchera villosa 'Caramel'. HortScience, 52: 622-624.

[33] Akasaka, Y., Daimon, H. and Mii, M. (2000): Improved plant regeneration from cultured leaf segments in peanut (Arachis hypogaea L.) by limited exposure to thidiazuron. Plant Science, 156: 169-175.

[34] Gharari, Z., Bagheri, K., Sharafi, A. and Danafar, H. (2019): Thidiazuron induced efficient in vitro organogénesis and regeneration of Scutellaria bornmuelleri: an important medicinal plant. In Vitro Cellular \& Developmental Biology-Plant, 55: 133-138.

[35] Fehér, A. (2015): Somatic embryogensesis-stress-induced remodeling of plant cell fate. Biochimica et Biophysica Acta BBA-Gene Regulatory Mechanisms, 1849: 385-402.

[36] Garcia, C., Furtado de Almeida, A-A., Costa, M., Britto, D., Valle, R., Royaert, S. and Marelli, J-P. (2019): Abnormalities in somatic embryogenesis caused by 2,4-D: an overview. Plant Cell, Tissue and Organ Culture, 137: 193-212.

[37] Krishna, H., Alizadeh, M., Singh, D., Singh, U., Chauhan, N., Eftekhari, M. and Sadh, R. K. (2016): Somaclonal variations and their applications in horticultural crops improvement. 3 Biotech, 6: 54. 
[38] Abd El-Kader, E. M. A., Serag, A., Aref, M. S., Ewais, E. E. A. and Farag, M. A. (2019): Metabolomics reveals ionones upregulation in MeJA elicited Cinnamomun camphora (camphor tree) cell culture. Plant Cell, Tissue and Organ Culture, 137: 309-318.

[39] Duan, Y., Su, Y., Chao, E., Zhang, G., Zhao, F., Xue, T., Sheng, W., Teng, J. and Xue, J. (2019): Callus-mediated plant regeneration in Isodon amethystoides using young seedling leaves as starting materials. Plant Cell, Tissue and Organ Culture, 136: 247-253.

[40] Kumar, R. R., Purohit, V.K., Prasad, P. and Nautiyal, A. R. (2018): Efficient in vitro propagation protocol of Swertia chirayita (Roxb. Ex Fleming) Kasrsten: A critically endangered medicinal plant. National Academic Science Letters, 4: 123-127.

[41] Lakshmi, S. R., Parthibhan, S., Sherif, N.A., Kumar, T. S. and Rao, M. V. (2017): Micropropagation, in vitro flowering, and tuberization in Brachystelma glabrum Hook.f., an endemic species. In Vitro Cellular \& Developmental Biology-Plant, 53: 64-72.

[42] Paliwal, A., Shekhawat, N. S. and Dagla, H. R. (2019): Micropropagation of Glossonema varians (Stocks) Benth. ex Hook.f.-a rare Asclepiadaceae of Indian Thar Desert. In Vitro Cellular \& Developmental Biology-Plant, 54: 637-641.

[43] Engelmann, F. (1991): In vitro conservation of tropical plant germplasm - a review. Euphytica 57: 227-243.

[44] Cha-um, S. and Kirdmanee, C. (2007): Minimal growth in vitro culture for preservation of plant species. Fruit, Vegetable and Cereal Science and Biotechnology, 1: 13-25.

[45] Roberts, E. H. (1973): Predicting the viability of seeds. Seed Science and Technology 1: 499-514.

[46] Shibli, R. D., Shatnawi, M. A., Subaih, W. S., Viera, R. F. and Ajlouni, M. M. (2006): In vitro conservation and cryopreservation of plant genetic resources: A review. World Journal of Agricultural Science, 2: 372-382.

[47] Staritsky, G., Dekkers, A. J., Louwaars, N. P. and Zandvoort, E. A. (1985). In vitro conservation of aroid germplasm at reduced temperatures and under osmotic stress. In: Withers, L. A. and Alderson, P. G. (Eds.). Plant Tissue Culture and its Agricultural Applications. Butterworths. Pp. 277-284.

[48] Espinoza, N., Estrada, R., Tovar, P., Bryan, J. and Dodds, J. H. (1985): Tissue culture micropropagation, conservation and export of potato germplasm. Specialized Technology Document 1. International Potato Center, Lima, Peru. 20 pp.

[49] Roca, W. M., Rodríguez, J., Beltran, J., Roa, J., and Mafla, G. (1982): Tissue culture for the conservation and international exchange of germplasm. In: Fujiwara, A. (Ed.). Proc, 5th Intl. Cong. Plant Tissue and Cell Culture, Tokyo. Pp.771-772.

[50] El-Bahr, M. K., El-Hamid, A. A., Matter, M. A., Shaltout, A., Bekheet, S. A. and El-Ashry, A. A. (2016): In vitro conservation of embryogenic cultures of date palm using osmotic mediated growth agents. Journal of Genetic Engineering and Biotechnolology, 14: 363-370.

[51] Camillo, J. and Scherwinski-Pereira, J. E. (2015): In vitro maintenance, under slow-growth conditions, of oil plan germplasm obtained by embryo rescue. Pesquisa Agropecuaria Brasileira 50: 426-429.

[52] Rayas, A., López, J., Medero, V. R., Basail, M., Santos, A. and Gutiérrez, Y. (2019): Conservación in vitro de cultivares de Ipomoea batatas (L.) Lam por crecimiento mínimo con el uso de manitol. Biotecnología Vegetal, 19: 43-51.

[53] Renau-Morata, B., Arrillaga, I. and Segura, I. (2006): In vitro storage of cedar shoot cultures under minimal growth conditions. Plant Cell Reports, 25: 636-642.

[54] Huang, H-P., Wang, J., Huang, L-Q., Gao, S-L., Huang, P. and Wang, D-L. (2014): Germplasm preservation in vitro of Polygonum multiflorum Thunb. Pharmacognosy Magazine, 10: 179-184.

[55] da Silva, T. L. and Scherwinski-Pereira, J. E. (2011): In vitro conservation of Piper aduncum and Piper hispidinervum under slow-growth conditions. Pesquisa Agropecuaria Brasileira, 46: 384-389. 